SECTION 18. Culturology.

Hasanov Elnur Latif oglu

Ph.D. postgraduate

scholar of Ganja Branch of Azerbaijan National Academy of Sciences,

Ganja, Azerbaijan

\title{
ABOUT TYPICAL CHARACTERISTICS OF CULTURAL DEVELOPMENT OF GANJA (XX-BEGINNING OF XXI CENTURIES)
}

Some main features of socio-cultural development of Ganja have been investigated. Also in article was researched the importance of this process and its basic typical characteristics.

Keywords: cultural development, Ganja, Azerbaijan, XX-XXI centuries

Ganja city that has glorious history and based on rich and ancient cultural heritage of the Caucasus, all history was known as a center of national self-esteem and honor. Ganja has always retained its image and has played a central role of national morality. For this reason, the highlevel expert in national history, the founder of the Independent Azerbaijan Republic, National Leader Heydar Aliyev, during all the years of his ruling approached special attention to the comprehensive development of Ganja. Thus, Ganja, under the leadership of the National Leader Heydar Aliyev, began second stage of huge development.

Thus, President Ilham Aliyev, during his ruling period, officially visited Ganja 12 times, and during his visits to the city, conducted practical measures for the development in social, economic and cultural spheres. Grateful for these measures of a number of important unsolved problems found positive results.

Everybody knows that the head of the country has a special occasion to Ganja and its history. Because of good geo-strategic, also economic and social usefulness Ganja is always in the center of attention.

In recent years, works in the direction of development of regions Ganja has been accompanied by to improving city infrastructure, working of social and production employments. The development program of Ganja has been prepared and is being successfully implemented now. A lot of visitings of President Ilham Aliyev to Ganja are remembered with the achievements and changes in the city life. As the result of attention of President Ilham Aliyev and president of the Heydar Aliyev's Foundation Mrs. Mehriban Aliyeva there has been done works in the field of rehabilitation of historical - monuments of Ganja [1-3].

The Flag Square, that has been built on the right bank of the Ganja river last period, is one of the most important projects. The length of the three-color flag, that fluctuating on the height of 100 meters, is 50 meters, width is 25 meters and 4 meters is height of pedestal. The national anthem and the national emblem of Azerbaijan are reflected on the granite panel on the square. Renovation and landscaping works were around the square. President Ilham Aliyev raised the national flag. The head of state expressed satisfaction with the work, that have done to the relevant instructions and recommendations.

In monument complex "Khamsa", that built in Ganja, are located Nizami Ganjavy's monument of and monuments for poems "Leili and Majnun", ”Sirler xezinesi "("The treasure of secrets"),”Yeddi gozel” ("Seven Beauties"), "Khosrov and Shirin", "Iskendername". Thus, there was created an extremely rare art monument, that reflects the creativity of Nizami .

Near Heydar Aliyev's Center, that is building in Ganja and will serve for the propaganda of national state values, will be built "Zefer Tagi" ( "Triumphal arch") with width 20, length 50, and height of 36 meters. Heydar Aliyev's Center will consist of three-storey building with 
total area of 4 thousand 500 square meters. There will be an exhibition hall on the first floor, excursion hall on the second floor, that reflects history of Azerbaijan and modern development, electronic and traditional library, supporting rooms on the third floor, conference halls and 400 seats session hall.

Restored by decree of President Ilham Aliyev's tomb on the project of Imamzade 36 cupolas, the cupola is installed 5. The head of state with the Order of the President's reserve fund of 3 million from the funds allocated for the repair and construction works carried out are of high quality. In accordance with instructions of Azerbaijani President Ilham Aliyev, each length of "Qala divari” (Tower walls) is built on both sides of highway Ganja-Baku is 47, height 15 meters, the castle tower height is 22 meters. Width of Ganja door's of the Tower is 5 , height is 7 meters. There will be national emblem on the upper part with the 6 meter diameter and will be bronze lion's monuments on each side of emblem. In front of the Qala ("Tower") there will be «Khamsa" spring. In addition, the 4.6-km-long road between "Qala" and Nizami's mausoleum complexes is reconstructed. Along the road there will be built architectural elements of the 5 great books ,that concern to"Khamsa" of Nizami Ganjavi, as well as the erection of monuments of the poet's immortal heroes and will be constructed fountains .

President Ilham Aliyev valued the importance of the first capital of Democratic Republic of Azerbaijan this kind: of " In all periods Ganja people have done most important works for being Azerbaijan as an independent country". High price of country's leader Ilham Aliyev to Ganja people shows, that they will use all the power for strengthening an Independent Azerbaijan, for its further development, and Ganja will be one of the most beautiful cities of Azerbaijan. The indissoluble connection between the nation and its head gives the reason to say it !

Thanks to purposeful policy pursued by President Ilham Aliyev for Ganja's development, today city is growing, developing, cultural and moral level is being more highly. The region's favorable climate, beautiful landscape, rich natural resources and human resources make Ganja famous as scientific, cultural, economic and industrial center just not only in Azerbaijan, even in the Middle and Nearest East.

The availability of rich ore and non-ore resources in the region contributed the development non-ferrous and ferrous metallurgy industry in the city, and operating large-scale enterprises that products aluminum and iron. The other fields of industry in the city: electronics, instrument-making plant, machinery and automobile industry have been operating as large industrial complexes.

The city's location on the ancient silk roads was the reason of developing spiritual to East tradition, and reflected national customs and traditions carpet weaving, knitting, sewing and other sectors of light industry and urban , and group of textile and weaving carpet enterprises, also the activity of sewing factory and other industrial enterprises have provided.

In the Middle Ages there were the perfect transportation system here. If in Europe underground transport was built in the middle of the twentieth century, in Ganja in the Middle Ages were two-storey underground roads system, where also phaeton could be used. In addition to the transport and movement of population there were also other communication systems.

Among the Middle East's transports, Ganja's transport infrastructure plays a most important role. The city's airport of international standards, is realize air flights to many countries of the world.

Vast scale Baku-Supsa, Baku-Tbilisi-Ceyhan oil pipeline, Baku-Tbilisi-Erzurum gas pipeline also are transported via the Ganja. Communication is one of the leading services of Ganja, that plays an important role in the socio-economic life of the city . The first Post Office in Azerbaijan was opened in Ganja. Mail expedition was established in Nakhchivan in 1828, and in Baku in 1836. 
The first Minister of Post and Telegraph of the first democratic republic in the East ADR was Ganjali Aga Ashurov. This ministry was located in the ancient building of Ganja's postoffice in present days.

The quick development of information and communication technologies in Ganja plays an important role in strengthening of statehood, the development of the economy, the regulation of social and political processes widen relations and enlightening the people. At present, mobile phone, Tran's registered mail, internet service and also other areas of technology informations are the foundation of communication service in Ganja. Ganja is one of the cities of Azerbaijan that has ancient history, rich culture, and unique tourism opportunities. Ganja's favorable natural and geographical position, pleasant climate, unique world of flora and fauna has always attracted tourists. Hajikend settlement, Koshku, Ashigli, Ezgilli, Chay kend and Togana kend were places of recreation of Ganjabasar. Also, Khoshbulag village is one of the most picturesque places of recreation of Ganjabasar. Approximately there are about 4800 residents and 1000 houses in the village. Meadow grasslands are green from early april till the middle of october. In some areas have been grown the artificial pine forests.

There are fifty springs (eg, Port-Port, Qible, the spring Kirk, etc.) and the river Karacefer here. In addition, on 3 kilometers far from Khoshbulag there is Zagaly lake with a wide magnificient view that, delight eyes, that colors nature. International Airport,that operate in Ganja, Railway Station, Bus Stations , 3,4,5 star hotels, historical monuments, cultural facilities, recreation and entertainment centers, modern sports facilities, restaurants and cafes, beautiful and mysterious corners of the nature, of the tourists happy,make conditions for happy ,interesting and memorable resting of tourists. From ancient times in watter supply of Ganja, that has a perfect communication system, underground-pipes pulled from Ganja and Qushqara river have played an important role. It is not accidental, that travellers, that come to Ganja, can't conceal their admirations, when they see Ganja's greenness cover, climate and rich water.

The city has always protected its exception in the world with valuable (mostly) grapes gardens, plane alleys. Therefore, Ganja's rose is famous not only in Azerbaijan, but also outside.

In general, climate and water supply system of Ganja have formed here the most favorable environment for the construction of parks and alleys, that are beautiful greenery and recreation centers. Recreation and culture park, named Heydar Aliyev, that differ with its immense and greatness, and also Khan Bagi (Khan's garden), that belongs to the ancient Turkic tribes to the kajars, are the most valuable evidence of our conceptions . Khan Bagi, that has a very beautiful view, for the richness of the plants is considered as a rare natural place. Parks and avenues, which is named Fuzuli, Nariman Narimanov, Fikret Amirov, park "Qelebe” (the "Victory") and others give such as special beauty to the city, and also turned the city to the favorite recreation place for the population of Ganja and for its guests.

After the capital Baku, Ganja is the second largest center of science and culture of Azerbaijan. Because of region, where located the city in the South Caucasus has very important strategic position, in the I-IV millennium the main caravan route, that connected trade centers of the Middle East and Front Asia, were here. The ancient city Ganja found development on this trade way and over thousands of years was one of the well-known cultural centers. Today, according to the history tradition, after the capital of Azerbaijan - Baku, Ganja is the second largest center of science and culture. Theater, music, museums and libraries, that reflecting the cultural level of the city, contributes development of the intellectual sphere.

The history of art and theatre is ancient in Ganja and its foundation begins with the initial period of human society. Even from the Middle Ages in Ganja in ceremonial and religious holidays there were shown square performances were performed different scenes. Performances, that shown by amateur troops and played scenes, accompanied by music, gave good mood to the population and made thinking them. Even at the end of the XIX century by 
amateur theater groups in Ganja have been staged plays of M.F. Akhundov, N. Narimanov, N.B. Vezirov and other well-known writers . In 1906, by amateur drama group has been created the 38-seat " Ganja Muslim drama party".

Well-known thinker, a patriot Ganja intelligent , an active member of the Party "Difai" and the society Mirza Muhammad Akhundov was founder of theater culture and wrote work " What is the Teatro?" about theater's role in society .

The first great national theater in Ganja was in 1933, on the basis of "Tengid-teblig theater" ( "critical-promoting theater") in Baku, that was founded in 1933. In 1954to Ganja's theater was giventhe name of well-known playwright Jafar Jabbarli. Ganja theater traditions are connected to such famous persons as M.Sheyxzamanov, M.Hemzeyev, B.Shekinskaya, I.Afandiyev, M.Davudov.

In this magnificent temple of art, were performed successfully several times not only Azerbaijani, but also Russian, European and world classics works. Alakbar Seyfi, Ismail Talibli, M. Burceliyev, Sedaye Mustafayeva, Ashraf Yusifzade, Aladdin Abbasovand other talented actors have created characters that opened in Ganja theater's history unforgettable pages.

An ancient cultural center of Azerbaijan Ganja is rightly proud of well-known persons and valuable contribution, that it has given to treasury of the world's musical culture.

An ancient Ganja and Ganjabasar is the land of Ozan's, the cradle and hot spring Ashuq's art. It becomes clear from the information in the book " Kitabi Dede Korkut" (VII century), that ozan's history in our territory is very ancient . Ozans, who had taken "Qolcha Gobuz" (an old Azerbaijani musical instrument) and shared from country to country, from man to man people's happiness and sadness, were the the leaders of people's parties . The most ancient stringed musical instrument gobuz is a predecessor of the modern ashuq's saz. Dede Korkud's expression "gobuz is sacred" shows respect of our nation to music.

In the Middle Ages in Ganja poets, musicians, wise men and artists had meetings and were talking about science, literature, music, art. An existence of such kind of meetings prove participation of the first well-known poetess of Azerbaijan, the first woman chess player and the first prominent female musician Mehseti Ganjavi (XII century)and other scientific and literary sources [2-5].

Creation heritageof the great poet and thinker of Azerbaijan Nizami Ganjavi (11411209) on the universal importance gave a rich information to the national culture, and also influenced to the development of literature and art .Nizami's characters have become the symbols of the culture of Azerbaijan. Many composers created vocal works, operas and ballets, symphony and other eternal music,that praised Nizami's poetry in music, and enriched world's culture.

In XI-XII centuries there were creative meetings in Ganja, where singer, musician and poets took part. In such meetings the representatives of literature and art of that period, including Mahsati Ganjavi, also took part.

Great Nizamy Ganjavy in his works has said the name of thirty popular musical instruments, that were widely spread in Azerbaijan at that time. This fact also proves that in XII century and more that earlier Azerbaijan people had high musical culture.

Ganja city, that has high music feeling and the music culture gave to the history of Azerbaijan national music such well-known composers as Meshedi Jamil Amirov,Fikret Amirov, Ganbar Huseynli, Zerif Gayibov, Telman Aliyev and Alakbar Tagiyev.

The love tradition to music lives in Ganja till nowadays. At present, State Philharmonic Society, "Goy-gol" State Song and Dance Ensemble, Orchestra of Folk Instruments, Ganja State Chamber Orchestra, music colleges, music schools are functioning in Ganja All genres of music - ashug, folk songs, opera, also the types of modern music have developed a high levelly in Ganja. More than 60 different medical institutions serve for the health of townsmen of 
Ganja. Currently, 20 hospitals, the Central Clinical Hospital, Eye diseases hospital, infectious diseases, Endocrinology, Psychiatry, 2 Children's Hospital, First Medical Aid, Railway hospitals, 13 Ambulatory polyclinics, 5 Dispenser, 3 Medical Sanitary Section; 9 Medical Center: Diagnosis, Ganja pensioners Territory Social Service, Ganja Railway Hygiene and Epidemiology, Reproductive Health and Family Planning, Esculap Medical Center, Orthopedic Prosthetic Center, Beauty and Health Center, 2 Consulting also the First Aid Station, Children's tuberculosis sanatorium and Maternity hospital are working here. In whole, there are 1387 doctors and 2622 nurseries work in medical centers of the city. The modern medical facilities, located in the city, are equipped with high-quality medical equipments [4-6].

\section{Bibliography:}

1. Guliyeva N.M., Hasanov E.L. Investigation of basic decorative-applied arts of Ganja on the basis of some innovative arguments and technologies / Science and Society: Proceedings of the 3rd International scientific-practical conference. London: SCIEURO, London, (Great Britain), 2013, p. 281-291

2. Həsənov E.L. Gəncə İmamzadə türbəsi (tarixi - etnoqrafik tədqiqat). Bakı: Elm və təhsil, 2012, $268 \mathrm{~s}$.

3. Häsänov E.L. Die Gändschänischen teppiche von XIX - XX Jahrhundert als geschichtliche - ethnographische quelle / European Science and Technology (Die Europäische Wissenschaft und die Technologien): $2^{\text {nd }}$ International scientific conference. Bildungszentrum Rdk e. V. Wiesbaden, (Germany) 2012, p. 26-27

4. Azərbaycan tarixi üzrə qaynaqlar. Bakı: Azərbaycan Universiteti nəşriyyatı, 1989, 328 s.

5. Hasanov E.L. Innovative approach to teaching and research of some traditional craft branches of Ganja of the end of XIX century // International journal of experimental education (Problems of international integration of national education standards: Proceedings of International scientific conference - France, Paris), 2013, № 2, p. 8183

6. Guliyeva N.M., Hasanov E.L. New ethnographic approach to the research of main decorative - applied arts of Ganja of the XIX - XX centuries / International scientific conference - Achievements in science: new views, problems, innovations. Lodz, (Poland) 2012, p. 56-58 